İşlek, M. S., Öztürk, E. (2021). “Uluslararası Değişim Öğrencilerinin Memnuniyet ve Uyumunun Tavsiye Etme Niyeti Üzerine Etkisi: Eskişehir Osmangazi Üniversitesi Örneği”, Eskişehir Osmangazi Üniversitesi iỉBF Dergisi, 16(1), 87 109.

Doi: $10.17153 / o g u i i b f .855809$

Başvuru: 07.01.2021

Kabul: 17.02.2021

Araştırma Makalesi/Research Article

\title{
Uluslararası Değişim Öğrencilerinin Memnuniyet ve Uyumunun Tavsiye Etme Niyeti Üzerine Etkisi: Eskişehir Osmangazi Üniversitesi Örneği
}

\begin{tabular}{|c|c|}
\hline $\begin{array}{l}\text { Uluslararası Değişim Öğrencilerinin Memnuniyet ve } \\
\text { Uyumunun Tavsiye Etme Niyeti Üzerine Etkisi: Eskişehir } \\
\text { Osmangazi Üniversitesi Örneği }\end{array}$ & $\begin{array}{l}\text { The Effect of International Exchange Students' } \\
\text { Satisfaction and Adaptation on the Intention to } \\
\text { Recommend: Example of Eskişehir Osmangazi } \\
\text { University }\end{array}$ \\
\hline $\begin{array}{l}\text { Öz } \\
\text { Uluslararasılaşma olgusu dünya üzerinde yer alan tüm } \\
\text { sektörleri ve kurumları etkilemiş ve yükseköğretim } \\
\text { kurumları da bu dinamiğe dâhil olmuştur. Yükseköğretim } \\
\text { kurumlarının uluslararasılaşmasına vesile olan bir araç da } \\
\text { uluslararası öğrencilerdir. Uluslararası öğrenci } \\
\text { memnuniyeti ve uyumun tavsiye etme niyeti üzerine } \\
\text { etkisini incelemeyi amaçlayan bu çalışmada son yedi } \\
\text { yılda Erasmus+ Öğrenim Hareketliliği ile yurt dışı } \\
\text { öğrenimine giden } 197 \text { öğrenciden anket yöntemi ile veri } \\
\text { toplanmıştır. Elde edilen veriler Yapısal Eşitlik } \\
\text { Modellemesi ile analiz edilmiştir. Araştırma bulgularına } \\
\text { göre uluslararası öğrencilerin uyum ve memnuniyeti } \\
\text { tavsiye etme niyeti üzerinde anlamlı bir etkiye sahiptir. } \\
\text { Ayrıca memnuniyet, uyum ve tavsiye etme niyeti } \\
\text { arasında tam aracı değişken rolü oynamaktadır. }\end{array}$ & $\begin{array}{l}\text { Abstract } \\
\text { The phenomenon of internationalization has affected all } \\
\text { sectors and institutions in the world and higher } \\
\text { education institutions have also been included in this } \\
\text { dynamic. International students are a means of } \\
\text { internationalization of higher education institutions. In } \\
\text { this study, we aim to examine the effect of international } \\
\text { student satisfaction and adaptation on the intention to } \\
\text { recommend, data were collected from } 197 \text { students who } \\
\text { went to study abroad with Erasmus + Learning Mobility } \\
\text { in last seven years. The data obtained were analyzed by } \\
\text { Structural Equation Modeling. According to the research } \\
\text { results, international students' adaptation and } \\
\text { satisfaction have a significant effect on their intention to } \\
\text { recommend. Also, satisfaction plays a full mediating role } \\
\text { between adaptation and the intention to recommend. }\end{array}$ \\
\hline $\begin{array}{l}\text { Anahtar Kelimeler: Uluslararasılaşma, Uyum, } \\
\text { Memnuniyet, Uluslararası Öğrenci, Yükseköğretim } \\
\text { Pazarlaması }\end{array}$ & $\begin{array}{l}\text { Keywords: Internationalization, Adaptation, Satisfaction, } \\
\text { International Student, Higher Education Marketing }\end{array}$ \\
\hline JEL Kodları: A2, M3 & JEL Codes: A2, M3 \\
\hline \multicolumn{2}{|c|}{$\begin{array}{l}\text { Bu çalışma (16/07/2020 tarih ve 2020/15 sayılı Eskişehir Osmangazi Üniversitesi Sosyal ve Beşerî Bilimler Bilimsel } \\
\text { Araştırma ve Yayın Etiği Kurulu) bilimsel araştırma ve yayın etiği kurallarına uygun olarak hazırlanmıştır. }\end{array}$} \\
\hline \multicolumn{2}{|c|}{ Yazar 1'in makaleye katkısı \%65., Yazar 2'nin makaleye katkısı \%35.'dir. } \\
\hline \multicolumn{2}{|c|}{ Yazarlar açısından ya da üçüncü taraflar açısından çalışmadan kaynaklı çıkar çatışması bulunmamaktadır. } \\
\hline
\end{tabular}

${ }^{1}$ Dr. Öğr. Üyesi., Eskişehir Osmangazi Üniversitesi, Turizm Fakültesi, Turizm İşletmeciliği Bölümü, msislek@ogu.edu.tr

${ }^{2}$ Yüksek Lisans Öğrencisi, Eskişehir Osmangazi Üniversitesi, İktisadi ve İdari Bilimler Fakültesi, Siyaset Bilimi ve Kamu Yönetimi Bölümü, elif.ozturk@ogu.edu.tr 


\section{Giriş}

21. yüzyıl bilgi toplumunun gelişimini ve bilginin yeni bir sermaye biçimine dönüşmesini işaret etmektedir. Sonuç olarak bilgi, gelişmekte olan ülkelerin ekonomik performanslarını ve kurumlarını iyileştirmelerine ve gelişmiş ülkeleri yakalayabilmelerine olanak tanıyan, kalkınma için de önemli bir varlık olarak karşımıza çıkmaktadır. Günümüz dünyasının küreselleşmiş doğası göz önüne alındığında yükseköğretimin uluslararasılaştırılması, gelişmekte olan ülkelere bilgiye erişim sağlamada anahtar bir strateji olmaktadır.

Yükseköğretimde uluslararasılaşmanın karakterini tam olarak anlamak için onu bir dizi farklı ancak iç içe geçmiş süreçlerle ilişkilendirmek gerekmektedir. Gerçekte uluslararasılaşma, yükseköğretimin uluslararası bağlamını sağlayan küreselleşme sürecinden bağımsız olarak analiz edilememektedir (Langthaler, 2009: 199). Genel olarak küreselleşme serbest piyasa eylemlerine dayanan ilişkileri oluşturma anlamında kullanılmaktadır (Maringe ve Foskett, 2012: 1). Eğitim açısından değerlendirildiğinde ise küreselleşme yükseköğretim dünyasına çok yönlü bir etkide bulunmaktadır. Küreselleşme sürecinde kurumlararası ilişkilerin giderek artması ile birlikte yükseköğretim kurumlarının uluslararası niteliği artış göstermektedir (Çetinsaya, 2014: 141). Bu noktada yükseköğretim kurumlarının uluslararasılaşmasında uluslararası değişim hareketliliği programları önemli bir rol oynamaktadır. Uluslararasılaşma faaliyetlerinde öğrenciler ise doğrudan rol oynayan aktörlerdir. Bu anlamda öğrencilerin uluslararasılaşmadan fayda elde etmesi beklenmektedir. Nitekim faydanın ortaya çıkması için de öğrencilerin uluslararasılaşmaya yönelik algılarının da olumlu olması gerekmektedir (Yemini vd., 2014). Uluslararası öğrenci hareketliliği, tüm dünyada gelişen ekonomilerde toplumsal ve eğitimsel dönüşümlerin kilit bir kaynağı olarak ortaya çıkmaktadır (Oleksiyenko vd., 2013). Yabancı dil bilgisi, farklı kültürlere aşina olmak ve yurt dışı tecrübesi gibi uluslararası yetkinlikler ve beceriler hem çalışanlar hem de işverenler tarafından giderek daha fazla değer görmektedir. Dahası uluslararasılaşma ile üniversiteler de taraflarına daha fazla değer yaratabilen kurumlar olmaktadırlar. Yükseköğretim kurumları hem öğrencileri hem de paydaşları için değer yaratabilmelidir. Birlikte değer yaratma süreci, yükseköğretim kurumlarının ve öğrencilerin, öğrenci deneyimini iyileştirmek için birlikte çalışmasına izin vermektedir ve öğrenci yetkinlikleri ile kurum kaynakları bütünleştirilerek daha iyi uygulamalara ve yeniliğe yol açabilecek değişim/etkileşimi teşvik eden bir dizi etkinlik ve deneyimi kolaylaştıran bir süreçtir (Dollinger, vd., 2018). Bu noktada da uluslararası öğrenci değişimi öğrenciler için önemli bir deneyim olanağı sunmaktadır.

Literatürde uluslararası öğrenci değişimi; ihtiyaçlarına yönelik algıları (Perez-Encinas ve Rodriguez-Pomeda, 2017), algılanan kültürel mesafe ve kültürleşme (Suanet ve Van de Vijver, 2009), uluslararası öğrenci hareketliliğinin belirleyicileri (Beine, Noël, ve Ragot, 2014), yurt dışında eğitim görmeye yönelik algıları (Chang, 2012), Erasmus hareketliliğinin profesyonel kariyer üzerindeki etkisi (Engel, 2010), hareketliliğin öğrencilerin becerileri ve istihdam edilebilirliği üzerindeki etkileri (European Commission, 2014) ve uluslararası öğrenci hareketliliği programlarının çıktıları (Roy vd., 2018) gibi konular üzerinde ele alınmıştır. Öğrencilerin uluslararası değişim programlarına katılma motivasyonlarına bakıldığında öncelikli sebeplerin yurt dışı deneyimi elde etme, yeni bir dil öğrenme veya yabancı dili geliştirme, yeni insanlar ile tanışma, girişkenlik, uyum sağlama gibi yetenekler geliştirmek ve gelecekte iş piyasasında daha tercih edilir bir profil olmayı istemeleri gibi sebepler olduğu görülmektedir. Diğer taraftan öğrencilerin neden değişim programına katılmadıklarına yönelik ifadelerde ise maliyetlerin belirsizliği, ailevi sebepler, yeterli finansal kaynağa sahip olmama, 
programa dair bilgi eksikliği, ev sahibi ve gönderen kurum arasında derslerin tanınmasına yönelik entegrasyon konuları öne çıkan sebepleri oluşturmaktadır (European Commission, 2014). Öğrencilerin kurum tercihlerine bakıldığında ise; Wang ve Tseng (2011)'in yaptığı araştırma sonucuna göre üniversitelerin öğretim üyelerinden öğrencilere daha verimli geri bildirimlerde bulunulması ve sundukları hangi faydaların iyi standartlara sahip olduklarını daha net göstermesi gerektiğini ayrıca güvenliğin de önemli görülmesi gerektiğini tespit etmişlerdir. Beine ve arkadaşları (2014), uluslararası öğrencilerin değişim için gidecekleri kurum seçiminin belirleyicilerini ele aldıkları araştırmalarında değişimin ekonomik maliyetinin önemli bir faktör olarak öne çıktığını, bunun yanında gidilecek ülkede öğrencinin geldiği ülkeden bir azınlığın veya küçük grupların bulunmasının tercihi etkilediğini belirtmektedir. Öğrencilerin ayrıca gidilecek ülkenin eğitim kalitesi ve yaşam masraflarını da dikkate alarak yer tercihi yaptığını da eklemişlerdir.

Moreira ve Gomes (2019) yurt dışında eğitim görme deneyiminin şehir ve üniversite çekiciliği faktörlerinin etkisi kapsamında nasıl oluştuğunu araştırmışlardır. Araştırma sonucuna göre yurt dışında eğitim alma nedenlerinin üniversiteye veya öğrenci kayıt türüne (değişim veya tam zamanlı) göre farklılık gösterdiğini, bunun yanı sıra üniversitelerin bulundukları şehrin öğrenci tercihine etkisinin sınırlı olduğunu fakat üniversitelerin küresel çekicilik endekslerinin büyük bir etkisinin olduğunu tespit etmişlerdir. Yemini ve arkadaşlarının çalışmasına göre (2014), ebeveynlerin eğitim düzeyi, yurt dışındaki önceki deneyimleri, yabancı dil yeterliliği ve uluslararasılaşma için kurumsal çabaların öğrencilerin kampüs içi uluslararasılaşma girişimlerine yönelik algılarını olumlu yönde etkilemektedir.

Yukarıda kısa bir şekilde özetlenmiş olan literatürden de anlaşılacağı üzere yükseköğretim kurumlarında uluslararasılaşmanın önemli bir konu olduğu ve yükseköğretim kurumlarının uluslararası pazarda tutunması için uluslararası öğrencilere yönelik yaklaşımların önem taşıdığı söylenebilir. Süreç dinamik bir yapıya sahip olduğundan yeni bakış açıları ve araştırmalara ihtiyaç duyulmaktadır. Bu araştırmanın amacı uluslararası öğrencilerin uyum ve memnuniyetinin tavsiye etme niyeti üzerindeki etkisini tespit etmek ve tavsiye etme niyetinde memnuniyet faktörünün aracı bir rol oynayıp oynamadığını belirlemektir. Illgili literatür incelendiğinde aracılık etkisini inceleyen çok az çalışma bulunmaktadır. Aracılık etkisi, uyumun doğrudan tavsiye etme niyeti üzerinde memnuniyetin etkisinin gerekli olup olmadığı konusunda bilgi sağlayacağından tespit edilmesi araştırma çıktılarına ek bir katkı sağlayacaktır. Bu bilgiler ışığında uluslararasılaşmanın bir aşaması olarak uluslararası değişim programlarının öğrencilere nasıl bir deneyim sunduğu açıklanmaya çalışılacaktır. Araştırma sonuçlarının üniversitelerin değişim programlarından faydalanan öğrencilerin memnuniyet, uyum ve tavsiye etme davranışları ile bunların birbirleriyle ilişkisi noktasında pratik öneriler ortaya çıkarması beklenmektedir. Ayrıca üniversiteler burada ortaya konulan bulgular ile hem kendi öğrencileri hem de dış paydaşları için daha etkili ve verimli pazarlama karar ve süreçlerine sahip olabilecek aynı zamanda hâlihazırda sahip oldukları bilgileri revize edebileceklerdir.

Çalışmanın bundan sonraki kısmında kavramsal çerçeveyi belirleyen kavramlar olan yükseköğretim kurumlarının uluslararasılaşması, uluslararası öğrenci memnuniyeti, tavsiye etme ve uyum davranışları ele alınmaktadır. Daha sonra, yapılan saha araştırmasına ilişkin bilgi ve bulgular paylaşılacaktır. Son olarak tartışma ve öneriler ortaya konulacaktır. 


\section{Yükseköğretim Kurumlarının Uluslararasılaşması}

Öğrenciler yükseköğretim kurumları için temel bir bileşen olması sebebiyle önemlidir. İngilizce'de "domestic" ya da "regular student" olarak karşıı̆ı̆ını bulan "daimi öğrenci", ilgili yükseköğretim kurumuna mezun olana kadar devam edeceğini taahhüt ederek kayıt olan öğrenciyi ifade etmektedir. Uluslararası öğrenci ise ilgili ülkeye sözleşmesinde yazan zaman diliminde staj veya öğrenim görme amacı ile gelen geçici öğrenciyi tanımlamaktadır.

Uluslararası ticarette uluslararasılaşma terimi, bir firmanın faaliyetlerinin dışa doğru hareketi olarak tanımlanmaktadır (Khan vd., 2016: 3). Yükseköğretimde uluslararasılaşmanın ise yaygın olarak kullanılan tanımı Knight (2008) tarafından yapılmıştır. Knight (2008)'a göre yükseköğretim kurumlarının uluslararasılaşması, kurumun öğrenciler ve personel gibi kilit paydaşlarının hızla değişen ve küreselleşen bir dünyaya entegre edilmesi sürecidir (Jibeen ve Khan, 2015: 196; Khan vd.; 2016: 4; Erişti vd., 2018: 353). Bu bağlamda uluslararasılaşma için üniversitelerin büyük oranda uluslararası hareketlilik faaliyetlerinde bulundukları söylenebilir. Yükseköğretim düzeyinde hareketlilik sağlamak amacıyla çok sayıda uygulama mevcuttur. Öğrenci ve öğretim elemanı değişimi, ortak eğitim programları geliştirme, stratejik işbirlikleri oluşturma karşılıklı diploma denkliği ve ders-kredi transfer sistemlerini yaşama geçirme, farklı ülkelerde kampüsler ve uluslararası yaz programları açma, uluslararası araştırma merkezleri kurma ve danışmanlık hizmetleri sunma örnek olarak verilebilmektedir. Yükseköğretimin uluslararasılaşması bağlamında gerçekleştirilen en yaygın uygulama ise öğrenci hareketliliğini sağlama ve karşılıklı değişim yoluyla uluslararası eğitim deneyiminin zenginleştirilmesi olmaktadır (Erişti vd., 2018: 354).

Yükseköğretim kurumları için kilit uluslararasılaşma faaliyetlerinin özeti Tablo 1'de sunulmaktadır.

Tablo 1: Yükseköğretim Kurumları İ̧̧in Kilit Uluslararasılaşma Faaliyetleri

\begin{tabular}{|c|c|}
\hline Ev Sahibi Kurumda Uluslararasılaşma & Yurt dışında Uluslararasılaşma \\
\hline $\begin{array}{l}\text { Uluslararası öğrencileri çekmek (Hem tam zamanlı programlar } \\
\text { hem de kısa değişim programları için) }\end{array}$ & Yerli öğrencileri uluslararası çalışmaya teşvik etmek \\
\hline Müfredat ve öğretim materyallerinin uluslararasılaştırılması & Uluslararası iş deneyimi yerleşimlerini desteklemek \\
\hline Yabancı dil programlarının sağlanması & Uluslararası araştırma bağlantıların artması \\
\hline Belirli ülke ve bölgesel programların sağlanması & $\begin{array}{l}\text { Personeli uluslararası alanda çalışmaya teşvik etmek } \\
\text { (hem öğretim hem de araştırma için) }\end{array}$ \\
\hline $\begin{array}{l}\text { Uluslararası akademik ve araştırma personelinin işe alımı ve } \\
\text { değişimi }\end{array}$ & $\begin{array}{l}\text { Ulus ötesi eğitim (uluslararası kurs ve programların } \\
\text { verilmesi) }\end{array}$ \\
\hline $\begin{array}{l}\text { Ortak öğretim programlarının artması (bölünmüş / ortak } \\
\text { dereceler veya diğer akreditasyon düzenlemeleri dâhil) }\end{array}$ & Ortaklık düzenlemeleri \\
\hline Araştırmada büyüyen uluslararası işbirliği & Ortaklık programlarının akreditasyonu \\
\hline Kampüste uluslararası faaliyetlerin teşvik edilmesi & Ortak / bölünmüş derece teklifleri \\
\hline Uluslararası etkinlik ve konferanslara ev sahipliği yapmak & Offshore kampüslerin kurulması \\
\hline Öğrenciler için uluslararası iş fırsatlarının teşvik edilmesi & Yurt dışındaki uzman araştırma merkezleri \\
\hline \multirow[t]{2}{*}{ Kurumsal yönetişim ve yönetimin uluslararasılaşması } & $\begin{array}{l}\text { Uluslararası kalkınma gündemi (kapasite geliştirme } \\
\text { veya teknik yardım projeleri) }\end{array}$ \\
\hline & $\begin{array}{l}\text { Uluslararası gönüllülük(kar amaçlı faaliyetler için } \\
\text { değil) }\end{array}$ \\
\hline
\end{tabular}

Kaynak: Mellors-Bourne vd., 2013: 4 
Khan ve arkadaşları (2016: 90-91) ise yükseköğretim kurumunun uluslararasılaşmasını dört madde ile açıklamaktadır. Bu adımlar;

- İthalat ve ihracat modları: İthalat yapmak için başvuruda bulunan akademik kurumlar kampüslerine dünyayı getirmektedir. İhracata güvenenler, öğrencilerini yurt dışına şu farklı yollarla gönderir: öğrenci değişim anlaşmaları ve yabancı üniversitelere ziyaretler (araştırma yapmak ve araştırma yapmak). Bu moda içe ve dışa uluslararasılaşma da denir.

- Akademik ortak girişimler: Tamamlayıc akademik programlar ve hizmetler sunan üniversiteler bu uluslararasılaşma tarzını (uluslararası ortak girişim olarak da adlandırılır) seçmektedir. Bu, çeşitli öğrencilerin yararlanabileceği (iki akademik kurum arasında) çift ve ortak diploma programları, sertifikalar, uzmanlık ve stajlar gibi farklı anlaşmalar kapsamında öğrenci değişim programları (içe ve dışa) gibi iş birlikleri içerir.

- Akademik ortaklıklar, ittifaklar ve konsorsiyumlar: Bu tür ortaklıklar altında, iki veya daha fazla akademik kurum ortaktır. Uluslararası ortaklıklar kurabilir ve çeşitli inisiyatiflerle (öğrenciler ve fakülte değişimleri, ortak programlar, fakülte araştırmaları vb.) iş birliği yapmayı taahhüt edebilirler.

- Yurt dışındaki kampüsler: Akademik kurumlar, firmaların doğrudan yabancı yatırımı gibi fiziksel varlık yoluyla da yurt dışına açılabilir. Yurt dışında yerli ve yabancı öğrencilere çeşitli akademik programlar ve hizmetler sunan kampüsler kurabilirler.

Kısaca yurt dışında başarılı iş birlikleri ve ortaklıklar kurmak ve yönetmek, birçok kurum için uluslararasılaşmanın kilit unsurlarından biridir. Bu tür ilişkiler öğrenciler için uluslararası deneyimler sağlayabilir, müfredatı geliştirebilir, gelir elde edilebilir ve kurumların görünürlüğünü artırabilir.

Üniversitelerin uluslararasılaşmasında yabancı uyruklu öğrenci alımının yanı sıra uluslararası değişim programları büyük önem taşımaktadır. Uluslararası değişim programlarına örnek olarak Erasmus+ Değişim Programı örnek olarak verilebilir. Erasmus+ Değişim Programı yabancı uyruklu tam zamanlı öğrenci olmaktan ziyade kısa süreli hareketlilik içeren bir öğrenim sürecidir. Chang (2012)'ın Tayvan'da yaptığı bir araştırmasında üniversite öğrencilerinin yurt dışında eğitim görme algıları ve hazırlıklı olma durumlarını ele almıştır. Buna göre öğrenciler Erasmus+ programında da olduğu gibi kısa dönemli programlarını uzun süreli programlara tercih etmektedir. Eğitimin bir düzeyinin tamamı yerine, belirli bir düzeyde bir süre başka bir kurumda bulunmak öğrencilerin daha çok tercih ettiği bir seçenek olmaktadır.

Erasmus+ programları ile elde edilen yurt dışı deneyimi, öğrencilerin sadece mesleki ve akademik yaşamlarını zenginleştirmekle kalmayıp, aynı zamanda açık fikirli olmayı, uyum yeteneğini ve esnekliği geliştirebilir veya dil öğrenimini, kültürlerarası becerileri, öz yeterliliği ve öz farkındalığı zenginleştirebilmektedir (European Commission, 2014). Iriondo (2020), Erasmus+ hareketliliğinin faydasını bir adım ileriye taşıyarak, programa katılan öğrencilerin mezun olduktan sonra iş bulma ve maaş durumlarını ele almaktadır. Erasmust öğrenim hareketliliğine katılmış olmak orta vadede ekonomik genişleme döneminde olumlu, ancak mezuniyetten bir yıl sonraki kriz döneminde istihdam beklentilerini olumsuz etkilemiştir. Ancak bu etkinin ikinci yıldan itibaren ortadan kalktığı görülmektedir. Maaşlar üzerine yapılan değerlendirmenin sonuçları, mezuniyetten altı yıl sonra, Erasmus+ hareketliliğinin pozitif bir etkiye sahip olduğunu ve maaşların \% 10 ile 12 arasında daha yüksek olduğunu ortaya koymaktadır. Amaro ve arkadaşları (2019) ise Portekiz'de Erasmus+ programına katılmıs olan değişim öğrencileri ile görüşmeler yapmış ve seyahat etme davranışları temelinde turizm 
açısından Portekiz'i nasıl tanıttıklarını anlamaya çalışmışlardır. Sonuç olarak, Erasmus öğrencilerinin, öğrencilikten sonra turist olarak, daha sonra da bir Portekiz turizm savunucusu olarak ülke turizmine katkı verdiğini ifade etmektedirler.

Kısa süreli uluslararası hareketliliğin öğrencilerin yetenekleri, yeterlilikleri ve becerileri üzerindeki etkisi bulunmaktadır. Roy ve arkadaşları (2019) öğrencide kısa süreli değişim hareketliliği sonrasında ortaya çıkan bu çıktıları kültürel, kişisel ve kariyer başlıkları altında el almışlardır. Buna göre genel olarak olumlu bir tecrübe olarak algılanan hareketliliğin detaylı olarak hangi çıktılara katkı verdiğini de görmek mümkün olmaktadır.

\section{3. Öğrenci Memnuniyeti}

Müşteri memnuniyeti ya da memnuniyetsizliği tanımlarında yer alan değişkenlik, memnuniyet kavramının tanımlanmasında tek geçerli ve doğru bir tanımın olmadığını göstermektedir. Bu kavrama dair en yaygın kullanılan tanım Hunt (1977: 49) tarafından yapılmaktadır. Buna göre memnuniyet bir ürünle ilgili olarak değerlendirildiğinde müşteri memnuniyeti olarak ifade edilir ve bireyin ürünü satın almakla veya kullanmakla ilişkili çeşitli sonuçlar ve deneyimler hakkındaki öznel değerlendirmesinin olumlu olup olmaması ile ilgilidir. Diğer yandan Oliver (1981: 27)'a göre memnuniyet, ürünle alakalı tüketim deneyiminin ya da ediniminin sonucunda ulaştığı o anki gerçek hislerinin değerlendirmesinde vardığı en iyi sonuçtur. Bazı yazarlar da, memnuniyetin "ürünün kendisi ile tüketim sonuçları hakkındaki bilişsel inançlardan" farklı olduğunu belirterek, memnuniyet ve bilgi arasında daha net bir ayrım önermektedirler (Westbrook, 1987: 260).

Öğrenci memnuniyeti, genellikle bir öğrencinin, eğitim deneyimi ile alakalı değerlendirmesinden kaynaklanan kısa vadeli bir tutum olarak kabul edilmektedir. Net sonuç ile öğrencinin beklentileri birbiri ile uyum gösterdiğinde öğrenci memnuniyeti ortaya çıkmaktadır. Hartman ve Schmidt (1995), öğrenci memnuniyetinin çok boyutlu bir yapıda olduğunu ve öğrenci hedeflerinin netliğine bağlı olduğunu belirtmektedirler. Sevier (1996), bir üniversitenin ürününün öğrencinin akademik, sosyal, fiziksel ve hatta ruhsal deneyimlerinin toplamı olduğunu savunmaktadır (Elliot ve Healy, 2001: 2). Bu araştırmada ise öğrenci memnuniyeti akademik destek hizmetleri, öğretim üyesi ilişkileri ve destek hizmetleri, sosyal etkileşim ve destek hizmetleri, kampüste yaşam ve kampüs iklimi çerçevesinde ele alınmıştır.

\subsection{Akademik Destek Hizmetleri}

Hizmet endüstrileri, birçok ülkenin ekonomisinde giderek daha önemli bir rol oynamaktadır. Günümüzde yükseköğretim, küresel eğitim piyasalarının gelişmesi ve yükseköğretim kurumlarını başka mali kaynaklar aramaya zorlayan devlet fonlarının azalması sonucu ekonomik güçler tarafından dayatılan ticari rekabete doğru yönlendirilmektedir (Abdullah, 2006: 33). Owlia ve Aspinwall (1997) tarafından yapılan bir araştırma, farklı profesyonellerin ve uygulayıcıların görüşlerine ve aynı zamanda yükseköğretimde kaliteye değinmiş ve yükseköğretimde müşteri odaklılığın genel kabul gören bir ilke olduğu sonucuna varmıştır. Bir yükseköğretim kurumundaki öğrenci deneyimi, performans göstergelerinin ele alması gereken temel bir konu olmalıdır. Bu nedenle, öğrencilerin birincil müşteriler olması açısından hizmet kalitesinin belirleyicilerini veya kritik faktörlerini belirlemek önemli hale gelmektedir. Zhai (2002), iyi organize edilmiş bir oryantasyonun uluslararası öğrencilerin üniversite yaşamının bazı yönlerinin farkına varmalarına ve daha sonra daha iyi uyum göstermelerine de yardımcı olabileceğini belirtmiştir. Bazı araştırmalarda ise rehberlik hizmetlerinin ve öğretim üyesi desteğinin uluslararası öğrenci memnuniyeti ve uyumu 
üzerindeki önemini vurgulanmaktadır. Trice ve Yoo (2007)'nun yaptığı bir çalışmada, uluslararası öğrencilerin akademik bölümlerden ve kurumlardan aldıkları destekten ne kadar memnun kaldılarsa yükseköğretim deneyimlerine o kadar değer verdiklerini ortaya koymuşlardır. Bir sınıftaki öğrencilerin deneyimleri, kampüs yaşamıyla ilgili diğer tüm deneyimlerden bağımsız olmamaktadır (Elliot ve Shin, 2002: 198). Örneğin, Browne ve arkadaşları (1998), bir üniversiteyle ilgili genel tatminin, öğrencinin dersin kalitesi ve ilgili yükseköğretim kurumunun ilişkili müfredatıyla ilgili diğer faktörlere ilişkin değerlendirmesinden kaynaklandığını tespit etmiştir. Özetle, akademik destek, uluslararası öğrencilerin üniversite yaşamında yollarını bulurken yaşadıkları deneyimlerde anahtar rol oynamaktadır (Cong, 2017: 18-19).

\section{2. Öğretim Üyesi îlişkileri ve Destek Hizmetleri}

Yükseköğretim kurumunun öğrenciler üzerindeki etkisi, örneğin; onların tutumları, değerleri, istekleri, kişilik özellikleri, mesleki seçimleri ve mezuniyet sonrası durumları üzerine önemli araştırmalar yapılmıştır. Bu kapsamda Endo ve Harpel (1982: 115), artan öğrenciöğretim üyesi etkileşiminin olumlu neticeler ortaya çıkardığı bulgusuna ulaşmışlardır.

\subsection{Sosyal Etkileşim ve Destek Hizmetleri}

Uluslararası öğrenciler birden fazla farklı grup içerisinde yer almakta ve bu gruplar içinde sosyal ağlarını oluşturan kişilerarası ilişkiler veya arkadaşlıklar, bir bağ oluşturmaktadırlar. Bir iletişim ağı analizine göre, belirli bir ağ yapısındaki bağların gücünün bireylerin başarı ve memnuniyetinde önemli bir rol oynadığını tespit etmiştir (Hendrickson vd., 2011: 282). Uluslararası öğrenciler, diğer öğrenciler gibi, daha bütünsel bir eğitim deneyimini tercih etmektedirler. Uluslararası öğrenciler sosyal etkileşim istemekte ve bu süreci kolaylaştıran yükseköğretim kurumunu olumlu değerlendirilme eğilimindedirler (Paswan ve Ganesh, 2009: 70).

\subsection{Kampüste Yaşam}

Kampüs yaşamını zenginleştiren unsurlar, yönetim/idare hizmetlerinin etkinliği, öğretim destek kaynaklarının yeterliliği, rahatlık ve güvenlik duygusu, maddi yardım ve burs bilgilerinin sağlanması ve bakım hizmetlerinin kalitesi gibi değişkenlerden oluşmaktadır (Paswan ve Ganesh, 2009: 69). Vize ve göçmenlik hizmetleri, tüm uluslararası öğrencilerin yasal olarak eğitim görmelerini ve çalışmalarını sağlamak için önemli bir unsurdur (Cong, 2017: 23). Athiyaman (1997), öğrenci yaşamının, öğrenci memnuniyetini etkileyen ve örtüşen, birbiriyle bağlantılı deneyimler ağı olduğunu belirtmektedir.

\subsection{Kampüs İklimi}

Mevcut literatür hem yerel hem de uluslararası öğrencilerin erişebileceği kapsayıcı bir kampüs ortamında öğrenmenin, olumlu yükseköğretim deneyimlerini ve gelecekteki gelişimi teşvik etmek için yararlı olduğunu göstermektedir. Konuksever ve kapsayıcı bir topluluk ortamı, uluslararası öğrencilerin aidiyet duygusunu artıran ve kültürleşme stresini azaltan temel faktörlerden biridir. Aidiyet, üniversite öğrencilerinin akademik başarısı için en sık belirtilen faktörlerden biridir. Öğrencilerin akademik ve sosyal etkileşimleri, yükseköğretim yaşamlarında aidiyet duygusuna katkıda bulunur. Çoğu uluslararası öğrenci için, kampüs topluluğuyla güçlü bir aidiyet ve özdeşleşme duygusu, üniversite deneyimini ve kültürel topluluğu keşfetmeleri için daha güvenli bir temel sağlamaktadır. Öğrencilerin okula ait olduklarını hissetme derecesi akademik deneyimlerini ve memnuniyetlerini olumlu yönde etkilemiştedir. Marka sadakati, kapsayıcı bir kampüs ikliminin katkıda bulunduğu başka bir 
yapıdır. Araştırmalar, eğitim hizmetlerinden ve deneyimlerinden daha memnun olan uluslararası öğrencilerin, kurumun savunucusu olma ihtimalinin daha yüksek olduğunu ileri sürmüştür. Uluslararası öğrencilerin olumlu iklime sahip bir kampüste yaşamaları ve okumaları önemlidir. Bu, onlara sadece hoş bir yükseköğretim deneyimi sağlamakla kalmaz, aynı zamanda uluslararası öğrenci memnuniyeti ve uyumu ile de olumlu bir şekilde ilişkilidir (Cong, 2017: 23).

\section{Uyum}

Uyum bir konuğun (sojourner) ev sahibi kültürün çeşitli yönleriyle sahip olduğu psikolojik olarak rahat hissetme derecesi olarak tanımlanmaktadır. Hem kurumun daimi öğrencileri hem de uluslararası öğrenciler kişisel otonomilerini geliştirme, akademik baskı, mali konular, sağlık konuları, yalnızık, bireylerarası çatışma gibi uyum sağlama faktörleri konusunda ortak özelliklere sahiptir fakat uluslararası öğrenciler ekstra zorluk yaşamaktadır. Bunun sebebi ise bu öğrencilerin evlerinden ve kendi ülkelerine ait kültürden uzak olmalarıdır (HechanovaAlampay vd., 2002: 459-460).

\subsection{Akademik Uyum}

Akademik uyum, bir öğrencinin akademik olarak başarılı olma potansiyeline ek olarak motivasyon, başarı, kurumsal bağlılık gibi faktörleri de kapsamaktadır. Uluslararası öğrenciler için akademik uyum, genel uyum sürecinde önemli bir bileşen olarak rol oynamaktadır (Bastien vd., 2018: 1201). Bir başka tanıma göre akademik uyum, öğrencilerin akademik anlamda başardıkları uyumu ifade etmektedir. Öğrenme süreçleri ise temelde, akademik bağlamla başa çıkmak için kişisel kaynaklarını genişleten bireylerin, bilgi ve becerileri edinme yollarını ifade etmektedir. Bununla birlikte öğrenme süreci, duygular, ruh halleri ve hisler tarafından kolaylaştırılmakta veya engellenmektedir (Ramsay vd., 1999: 130). Bunlarla birlikte Anderson (1994), çoğu kısa vadeli uyumun uzun vadeli sonucuna atıfta bulunduğu bir kültürler arası adaptasyon modeli sunmaktadır. Uyum sırasında gerçekleşen öğrenmenin duyguların ve bilişlerin karşılıklı etkileşimini ve ardından ilişkili eylemleri içerdiğini ileri sürmektedir. Model, özellikle uyumdaki bilişsel süreçlere odaklanmaktadır; burada uyum ve öğrenme, bütünsel olarak ilişkili ve döngüseldir. Anderson'ın modelinin dört ana bileşeni vardır. İlk olarak genel bir "kültürel karşılaşma" ile başlamaktadır. İkinci aşamada, insanların daha sonra ya çevre ya da kendisinden kaynaklı "engelleri" deneyimlemesi önerilmektedir. Engeller, üçüncü aşamada çeşitli türlerde "yanıt oluşturma" ya yol açmaktadır. Dördüncü aşamada ise, genellikle uyuma ulaşılan "aşma" aşamasıdır. Burada, dört aşamanın her birinde duygusal, bilişsel ve davranışsal tepkiler meydana gelmektedir. Böylelikle, her aşamada kişinin, önce düşünme süreçlerine ardından da durumu etkilemek için tasarlanmış belirli davranışlara götüren duygusal tepkiler deneyimlediği ve bunların tümü doğrudan bireyler için öğrenme ve uyumla ilgili olduğu ileri sürülmektedir. Nihayetinde, kişi kültürler arası durumu anlayabilmekte ve ona uyum sağlayabilmektedir (Ramsay vd., 1999: 130).

Ramsay ve arkadaşları (1999) tarafından uluslararası öğrencilerle yapılan bir araştırmaya göre öğrencilerin yükseköğretim kurumu bağlamında kişisel olarak anlamlı çok çeşitli olumlu ve olumsuz öğrenme olaylarını kolayca yaşayabileceğini tespit etmiştir. Öğrenciler ayrıca belirli olaylara tepki olarak bir dizi duygu, biliş ve davranış göstermişlerdir. Bu nedenle Ramsay ve arkadaşlarının çalışması, Anderson'un (1994) kültürler arası uyum modeli ile benzer sonuçları sağlamakta ve öne sürülen fikri desteklemektedir. 


\subsection{Sosyal Uyum}

Kültürleşme hem kültürleşen bireylerde hem de ev sahibi çevrede kültürel ve psikolojik değişikliklerin meydana geldiği karşılıklı bir süreçtir. Uluslararası öğrenci bağlamında, uluslararası öğrenci kültürler arası uyum sürecinin sonuçları, uluslararası öğrenciler ve ev sahibi çevre arasındaki etkileşimin kalitesinden önemli ölçüde etkilenmektedir (Bui vd., 2020: 2).

Uyum sorunları kişi için ciddi sonuçlar doğurabilir. Örneğin, Thomson ve English (1964), yaptıkları bir araştırmada kişilerin \% 60'ından fazlasının başkalarına, çevreye ve ev sahibi kültür içindeki faaliyetlerine karşı uyum sorunlarının oluşturduğunu belirtmişlerdir.

Kişinin uyumu konusunu anlamada önemli bir sorun, çeşitli araştırmacıların yaklaşımlarının birbirinden farklı olmasıdır ki bulgularını birbiriyle ilişkilendirmek veya kültürlerarası uyumla ilgili olduğu düşünülen faktörler arasında herhangi bir tutarlılık geliştirmek zor olmaktadır. Dahası, araştırmacılar görünüşte aynı veya benzer faktörleri incelediklerinde bile, sonuçlar genellikle herhangi bir tutarlı model göstermede başarısız olmaktadır.

Tinto $(1975,1998)$ 'nun öğrencilerin öğrenimi hangi nedenlerle bıraktıklarını gösteren modelinde, öğrencilerin yükseköğretime başlamadan önce çeşitli eğitim deneyimlerine, yeterliliklerine ve becerilerine, değerlerine ve ayrıca aile ve toplum geçmişine sahip olduğunu düşünmektedir. Sonuç olarak, hem bireysel hem de sosyal özellikler öğrencinin yükseköğretime uyumunu etkileyecektir. Tinto $(1975,1998)$ 'ya göre, öğrencilerin mezun olmak için (yani akademik uyum) sadece çalışmalarında istikrar sağlamaları yetmiyor, aynı zamanda öğrenme ortamının hem içinde hem de dışında öğrenci kültürüne katılmaları gerekmektedir bu da sosyal uyuma işaret etmektedir (Rienties vd., 2012: 687).

Avustralya'da Russell ve arkadaşları (2010) tarafından, yaklaşık 900 uluslararası öğrenci arasında yapılan bir çalışmada, uluslararası öğrencilerin \% 41'inin, genellikle vatan özlemi, kültürel şoklar veya algılanan ayrımcılığın sonucunda önemli düzeyde stres yaşadığını tespit etmişlerdir. Yerli öğrencilere kıyasla uluslararası öğrenciler, aileleri, kendi ülkelerinden arkadaşları ve sosyal ağlarına çoğunlukla kolay ulaşılamayacağı için uluslararası öğrencilerin sosyal uyumuna daha fazla dikkat ve çaba göstermeleri gerekmektedir (Rienties vd., 2012).

\subsection{Kişisel Duygusal Uyum}

Parr ve arkadaşlarının (1992) yaptığı bir araştırmaya göre, uluslararası öğrencilerin sinirlilik, sağlıkla ilgili aşırı endişe, ev sahibi kültürün üyelerine karşı güvensizlik ve düşmanlık, depresyon ve düşük iş performansı gibi yaşadığı durumlar kültürel şokun ortak belirtileri olmaktadır. Baker ve Siryk (1999)'e göre, kişisel ve duygusal uyum, yerel akademik yaşam tarzına uyum sağlarken psikolojik ve fiziksel sıkıntının seviyesini göstermektedir (Rienties vd., 2012: 689). Mevcut akademik ortamda öğrencilerin karşılaştıkları uyum zorlukları psikolojik sıkıntılara yol açabilmektedir. Yükseköğretim öğrencileri arasında karmaşık ve önemli psikolojik sorunların görülme sıklığı artmaktadır. Yükseköğretim öğrencilerinin yüzde ellisinden fazlasının çalışmalarının başlamasından hemen sonra depresif belirtiler gösterdiğini tespit etmişlerdir. Sıkıntılar, uluslararası öğrenciler için yerel öğrencilerden daha belirgin olabilmektedir. Janca ve Hetzer (1992), iki grup için psikolojik olarak rahatsılık oranlarını karşılaştırmış ve uluslararası öğrencilerin daha yüksek oranlara sahip olduğunu bulmuşlardır. Yeni bir kültürle karşılaşmak kişisel gelişim ve gelişme potansiyeli sağlayabilmekte ancak daha yaygın olarak süreç zorluklarla dolu olabilmektedir (Khawaja ve Dempsey, 2008: 7-8). 


\subsection{Arkadaşlık}

Arkadaşlık, derin, kişisel ve duygusal ihtiyaçlarını karşılamada bireyler için son derece önemli bir bileşendir (Hendrickson vd., 2011: 282). Antwi ve Ziyati (1993), uluslararası öğrencilerin kendi ülkeleri ve kültürleri dışındaki yaşamlarını, iletişim temelli deneyimler olduğunu varsaymışlardır. Bulgular, farklı kültürler arasında etkileşimi ve anlayışı zorlaştıran bir dizi engel ve engelin varlığını ortaya koymuştur. Bu engeller arasında yoğun izolasyon, yalnızlık ve hayal kırıklığı duyguları bulunmaktaydı. Chen (1996), uluslararası öğrencilerin yalnızlığının, yoğun akademik çalışma yükü ve dilin kısıtılığı nedeniyle yeni arkadaşlar edinmeye zamanları olmamasından kaynaklandığını belirtmiştir (Zhai, 2002: 6).

\section{Tavsiye Etme Niyeti}

Gittikçe daha rekabetçi hale gelen küresel pazarda, kurumların, özellikle memnuniyet derecelendirmelerini ve kurumsal tavsiyeleri iyileştirme açısından uluslararası öğrencilerin tercihlerini algılamalarına ve deneyimlerine özen göstermeleri hayati önem taşımaktadır. Kurumsal tavsiye kavramı, memnun öğrencilerin kurumlarını gelecekteki öğrencilere tavsiye etme olasılıklarının daha yüksek olması anlamında memnuniyetle yakından ilişkilidir. Ayrıca, bu öğrencilerin daha yüksek derecelere kayıt yaptırmak için değerli mezunlar haline gelme ve mevcut öğrencilere işe yerleştirme fırsatları sunma olasılıkları daha yüksektir. Uluslararası öğrencilerin seçme ve kuruma karar vermeleri, kurumun ünü, güvenliği, çevresi ve yaşam kalitesi vb. faktörlere bağlıdır (Ammigan, 2019: 268).

Browne ve arkadaşları (1998), bir öğrencinin üniversiteyi arkadaşlarına/akrabalarına tavsiye etme olasılığında fakülte ve yükseköğretim kurumu personelinin öğrenci ile etkileşiminin büyük kapsamda rol oynadığını belirtmişlerdir (Elliot ve Healy, 2001: 2-3).

\section{Araştırma Yöntemi}

Uluslararası değişim öğrencilerinin memnuniyet ve uyumunun tavsiye etme niyeti üzerine etkisini tespit etmeyi amaçlayan bu araştırmada yapısal eşitlik modeli kullanılarak araştırmada yer alan hipotezler test edilmiştir.

\subsection{Araştırmanın Modeli}

Uluslararası değişim öğrencilerinin memnuniyet ve uyumunun tavsiye etme niyeti üzerine etkisini gösteren model Şekil 1'de sunulmuştur. Modele göre öğrenci memnuniyeti, uyum ve tavsiye etme niyeti arasında aracı bir rol oynamaktadır. 




Araştırma modeline dayanarak araştırmada yer alan hipotezler aşağıda sıralanmaktadır.

$\mathrm{H}_{1}$ :Uyum ve öğrenci memnuniyeti arasında pozitif yönde bir ilişki bulunmaktadır.

$\mathrm{H}_{1 \mathrm{a}}$ : Akademik uyum ve öğrenci memnuniyeti arasında pozitif yönde bir ilişki bulunmaktadır.

$\mathrm{H}_{1 b}$ : Sosyal uyum ve öğrenci memnuniyeti arasında pozitif yönde bir ilişki bulunmaktadır.

$\mathrm{H}_{1 c}$ : Kişisel duygusal uyum ve öğrenci memnuniyeti arasında pozitif yönde bir ilişki bulunmaktadır.

$\mathrm{H}_{1 \mathrm{~d}}$ : Arkadaşlık ve öğrenci memnuniyeti arasında pozitif yönde bir ilişki bulunmaktadır.

$\mathrm{H}_{2}$ :Öğrenci memnuniyeti ve tavsiye etme niyeti arasında pozitif yönde bir ilişki bulunmaktadır.

$\mathrm{H}_{2 \mathrm{a}}$ : Akademik destek hizmetleri ve tavsiye etme niyeti arasında pozitif yönde bir ilişki bulunmaktadır.

$\mathrm{H}_{2 b}$ : Öğretim üyesi ilişkileri ve destek hizmetleri ve tavsiye etme niyeti arasında pozitif yönde bir ilişki bulunmaktadır.

$\mathrm{H}_{2 c}$ : Sosyal etkileşim ve destek hizmetleri ve tavsiye etme niyeti arasında pozitif yönde bir ilişki bulunmaktadır.

$\mathrm{H}_{2 \mathrm{~d}}$ : Kampüste yaşam ve tavsiye etme niyeti arasında pozitif yönde bir ilişki bulunmaktadır.

$\mathrm{H}_{2 \mathrm{e}}$ : Kampüs iklimi ve tavsiye etme niyeti arasında pozitif yönde bir ilişki bulunmaktadır. 


\section{$\mathrm{H}_{3}:$ Uyum ve tavsiye etme niyeti arasında pozitif yönde bir ilişki bulunmaktadır.}

$\mathrm{H}_{3 a}$ : Akademik uyum ve tavsiye etme niyeti arasında pozitif yönde bir ilişki bulunmaktadır.

$\mathrm{H}_{3 b}$ : Sosyal uyum ve tavsiye etme niyeti arasında pozitif yönde bir ilişki bulunmaktadır.

$\mathrm{H}_{3 c}$ : Kişisel duygusal uyum ve tavsiye etme niyeti arasında pozitif yönde bir ilişki bulunmaktadır.

$\mathrm{H}_{3 \mathrm{~d}}$ : Arkadaşlık ve tavsiye etme niyeti arasında pozitif yönde bir ilişki bulunmaktadır.

\section{$\mathrm{H}_{4}$ :Öğrenci memnuniyetinin uyum ve tavsiye etme niyeti arasında aracılık rolü bulunmaktadır.}

Uluslararası öğrenci memnuniyeti ve uyumunun tavsiye etme niyeti ile ilişkisini incelemeyi amaçlayan bu çalışmanın araştırma evrenini 2013-2014, 2014-2015, 2015-2016, 2016-2017, 2017-2018, 2018-2019, 2019-2020 dönemlerinde Erasmus+ Öğrenim Hareketliliği ile yurt dışına öğrenime giden Eskişehir Osmangazi Üniversitesi öğrencileri oluşturmaktadır. Bu doğrultuda öğrencilere e-posta yoluyla 34'ü 5'li Likert Tipi ifadelerden, 10'u ise demografik değişkenlerden oluşan bir çevrim içi anket gönderilmiştir.

Araştırma evrenini 1029 öğrenci oluşturmaktadır. Anketin öğrencilere ilk gönderimi 06.08.2020 tarihinde olmuş toplamda 109 yanıt alınmıştır. İkinci gönderim 10.08.2020 tarihinde olmuş toplamda 46 yanıt alınmıştır. Üçüncü gönderim 15.08.2020 tarihinde olmuş toplamda 44 yanıt alınmıştır. Son gönderim ise 18.08 .2020 tarihinde olmuş ve 2 kişiden yanıt alınmıştır. Süreç sonunda elde edilen toplam örnek hacmi 201 olmuştur. 4 hatalı veri olduğu için örnek hacminden silinmiş ve geriye 197 geçerli veri kalmıştır. Ayrıca veri toplama sürecine başlamadan önce Eskişehir Osmangazi Üniversitesi Sosyal ve Beşeri Bilimler Bilimsel Araştırma ve Yayın Etiği Kurulundan gerekli izinler alınmıştır (Toplantı Tarihi: 16.07.2020, No: 2020-15).

Anket formunda yer alan memnuniyet ve uyum ölçekleri Cong (2017)'un araştırmasından uyarlanmıştır. Tavsiye etme niyeti ise Aydın ve Tavukçu (2019)'nun çalışmasından uyarlanmıştır. Araştırmada kullanılan ölçeğe ilişkin yapılan güvenirlik analizleri Tablo 2'de sunulmaktadır.

Tablo 2: Araştırmada Kullanılan Ölçeklerin Güvenirlik Analizleri

\begin{tabular}{l|l}
\hline Faktör & Cronbach's Alpha Değeri \\
\hline Öğrenci Memnuniyeti &, 944 \\
\hline Akademik Destek Hizmetleri &, 880 \\
Öğretim Üyesi Ilişkileri ve Destek Hizmetleri &, 833 \\
Sosyal Etkileşim ve Destek Hizmetleri &, 894 \\
Kampüste Yaşam &, 822 \\
Kampüs İklimi &, 799 \\
\hline Uyum &, 927 \\
\hline Akademik Uyum &, 824 \\
Sosyal Uyum &, 835 \\
Kişisel Duygusal Uyum &, 863 \\
Arkadaşlık &, 712 \\
\hline Tavsiye Etme Niyeti &, 904 \\
\hline
\end{tabular}

Güvenirlik katsayıları;

$0 \leq \alpha<0,5$ ise güvenilir değil,

$0,5 \leq \alpha<0,6$ ise düşük derecede güvenilir,

$0,6 \leq \alpha<0,7$ ise kabul edilebilir derecede güvenilir, 
$0,7 \leq \alpha<0,9$ ise yüksek derecede güvenilir,

$\alpha>0,9$ ise çok yüksek derecede güvenilir olduğu kabul edilir (Güriş ve Astar, 2019: 306).

Tablo 2'de de görüldüğü üzere çalışmada yer alan ölçeğin güvenirliği oldukça yüksektir.

\subsection{Betimleyici İstatistikler}

Araştırmaya ilişkin öğrencilerin demografik özellikleri Tablo 3'te sunulmuştur.

Tablo 3: Öğrencilerin Demografik Özellikleri

\begin{tabular}{|c|c|c|c|c|c|}
\hline Cinsiyet & $\mathbf{N}$ & $\%$ & Sinıf & $\mathbf{N}$ & $\%$ \\
\hline $\begin{array}{l}\text { Kadın } \\
\text { Erkek } \\
\text { Toplam }\end{array}$ & $\begin{array}{l}101 \\
96 \\
197 \\
\end{array}$ & $\begin{array}{l}51,3 \\
48,7 \\
100\end{array}$ & $\begin{array}{l}\text { 2. Sinif } \\
\text { 3. Sinıf } \\
\text { 4. Sinif }\end{array}$ & $\begin{array}{l}59 \\
89 \\
45\end{array}$ & $\begin{array}{l}29,9 \\
45,2 \\
22,8\end{array}$ \\
\hline Yaş Aralığı & $\mathbf{N}$ & $\%$ & 5. Sinıf & 2 & 1,0 \\
\hline $\begin{array}{l}17-20 \\
21-24\end{array}$ & $\begin{array}{l}23 \\
123\end{array}$ & $\begin{array}{l}11,7 \\
62,4\end{array}$ & $\begin{array}{l}\text { 6. Sinif } \\
\text { Toplam }\end{array}$ & $\begin{array}{l}2 \\
197 \\
\end{array}$ & $\begin{array}{l}1,0 \\
100\end{array}$ \\
\hline $25-28$ & 43 & 21,8 & Fakülte & $\mathbf{N}$ & $\%$ \\
\hline $\begin{array}{l}29+ \\
\text { Toplam }\end{array}$ & $\begin{array}{l}8 \\
197\end{array}$ & $\begin{array}{l}4,1 \\
100\end{array}$ & $\begin{array}{l}\text { Eğitim Fakültesi } \\
\text { Turizm Fakültesi }\end{array}$ & $\begin{array}{l}34 \\
2\end{array}$ & $\begin{array}{l}17,3 \\
1,0\end{array}$ \\
\hline Dönem & $\mathbf{N}$ & $\%$ & Müh. Mimarlık F. & 110 & 55,8 \\
\hline 2013-2014 & 13 & 6,6 & Fen Edebiyat $\mathrm{F}$. & 16 & 8,1 \\
\hline 2014-2015 & 11 & 5,6 & iiBF & 21 & 10,7 \\
\hline $2015-2016$ & 26 & 13,2 & Tıp Fakültesi & 3 & 1,5 \\
\hline 2016-2017 & 24 & 12,2 & San.ve Tasarım F. & 3 & 1,5 \\
\hline 2017-2018 & 32 & 16,2 & Sağlık Bil. Fakültesi & 1 & 0,5 \\
\hline 2018-2019 & 34 & 17,3 & Fen Bil. Enstitüsü & 5 & 2,5 \\
\hline 2019-2020 & 57 & 28,9 & Sosyal Bil. Enst. & 1 & 0,5 \\
\hline Toplam & 197 & 100 & Toplam & 196 & 99,5 \\
\hline Yarıyıl & $\mathbf{N}$ & $\%$ & İngilizce Yeterliliği & $\mathbf{N}$ & $\%$ \\
\hline Güz & 119 & 60,4 & B1 & 31 & 15,7 \\
\hline Bahar & 78 & 39,6 & B2 & 92 & 46,7 \\
\hline Toplam & 197 & 100 & $\mathrm{C} 1$ & 60 & 30,5 \\
\hline Program & $\mathbf{N}$ & $\%$ & $\mathrm{C} 2$ & 14 & 7,1 \\
\hline Lisans & 182 & 92,4 & Toplam & 197 & 100 \\
\hline Yüksek L. & 11 & 11 & Ülke & $\mathbf{N}$ & $\%$ \\
\hline Doktora & 4 & 4 & İtalya & 17 & 8,6 \\
\hline Toplam & 197 & 100 & Litvanya & 23 & 11,7 \\
\hline Ülke & $\mathbf{N}$ & $\%$ & Makedonya & 8 & 4,1 \\
\hline Avusturya & 1 & 0,5 & Polonya & 22 & 11,2 \\
\hline Belçika & 2 & 1,0 & Portekiz & 13 & 6,6 \\
\hline Bulgaristan & 2 & 1,0 & Romanya & 42 & 21,3 \\
\hline Hırvatistan & 7 & 3,6 & Sırbistan & 1 & 0,5 \\
\hline Çekya & 25 & 12,7 & Slovakya & 2 & 1,0 \\
\hline Estonya & 11 & 5,6 & Slovenya & 4 & 2,0 \\
\hline Finlandiya & 2 & 1,0 & İspanya & 4 & 2,0 \\
\hline Fransa & 4 & 2,0 & İsveç & 1 & 0,5 \\
\hline Almanya & 2 & 1,0 & Toplam & 197 & 100 \\
\hline Macaristan & 4 & 2,0 & & & \\
\hline
\end{tabular}

Araştırmaya katılan öğrencilere ait demografik değişkenler incelendiğinde kadın öğrencilerin oranı $\% 51,3$, erkek öğrencilerin ise 48,7 olduğu görülmektedir. Bu verilere göre araştırmaya katılan kadın ve erkek öğrencilerin sayılarının birbirine yakın olduğu söylenebilir. Sınıf incelendiğinde en çok katılım \% 45,2 ile 3. sınıf öğrencilerinden oluşmuştur. Yaş aralığı incelendiğinde ise en çok \% 62,4 ile 21-24 yaş aralığından öğrencinin katılım gösterdiği 
anlaşılmaktadır. Bu durumun katılımın daha çok üçüncü sınıf öğrencilerinin oluşturmasından kaynaklandığı düşünülmektedir. Dönem incelendiğinde en çok katılım \% 28,9 ile 2019-2020 döneminden öğrenciler göstermiştir. Bu durum ise öğrencilerin yeni olması sebebi ile kolay ulaşılabilir olmasından kaynaklanabilir. Yarıyıl incelendiğinde en çok katılımı \% 60,4 ile güz döneminde hareketlilik gösteren öğrenciler göstermiştir. Bu durum projelerin ilk başvuru alımının güz dönemine denk gelişi sebebi ile başvurunun daha fazla olmasından kaynaklanabilir. Program incelendiğinde en çok katılımı \% 92,4 ile lisans öğrencileri oluşturmuştur. Bu durum lisans öğreniminde öğrencilerin hem sayı hem de müfredat açısından daha uygun olmasından kaynaklanabilir. İngilizce yeterliliği incelendiğinde en yüksek düzey \% 46,2 ile B1 seviyesidir. Fakülte incelendiğinde \% 55,8 ile en çok Mühendislik Mimarlık Fakültesi öğrencileri katılım göstermiştir. Bölüm olarak ise \% 13,7 ile Makine Mühendisliği öğrencileri katılım göstermiştir. Bu durum öğrencilerin hem dil seviyesinin hem de müfredatlarının ders eşleşmesi açısından daha uygun olmasından kaynaklanabilir. Hareketlilik gerçekleştirilen ülke incelendiğinde en çok hareketlilik gerçekleştirilen ülke \% 21,3 ile Romanya olmaktadır. Bu durumun ülkenin maddi olarak öğrencilere daha uygun bir ortam sunmasından ve üniversitenin bölümler itibariyle sahip olduğu ikili anlaşmalardan kaynaklandığı düşünülmektedir.

\subsection{Araştırmaya İlişkin Doğrulayıcı Faktör Analizi ve Hipotezlerin Test Edilmesi}

Araştırmaya haiz verilerin Doğrulayıcı Faktör Analizi sonuçları Şekil 2'de ve Tablo 5'te sunulmuştur.

\section{Şekil 2: Doğrulayıcı Faktör Analizi}

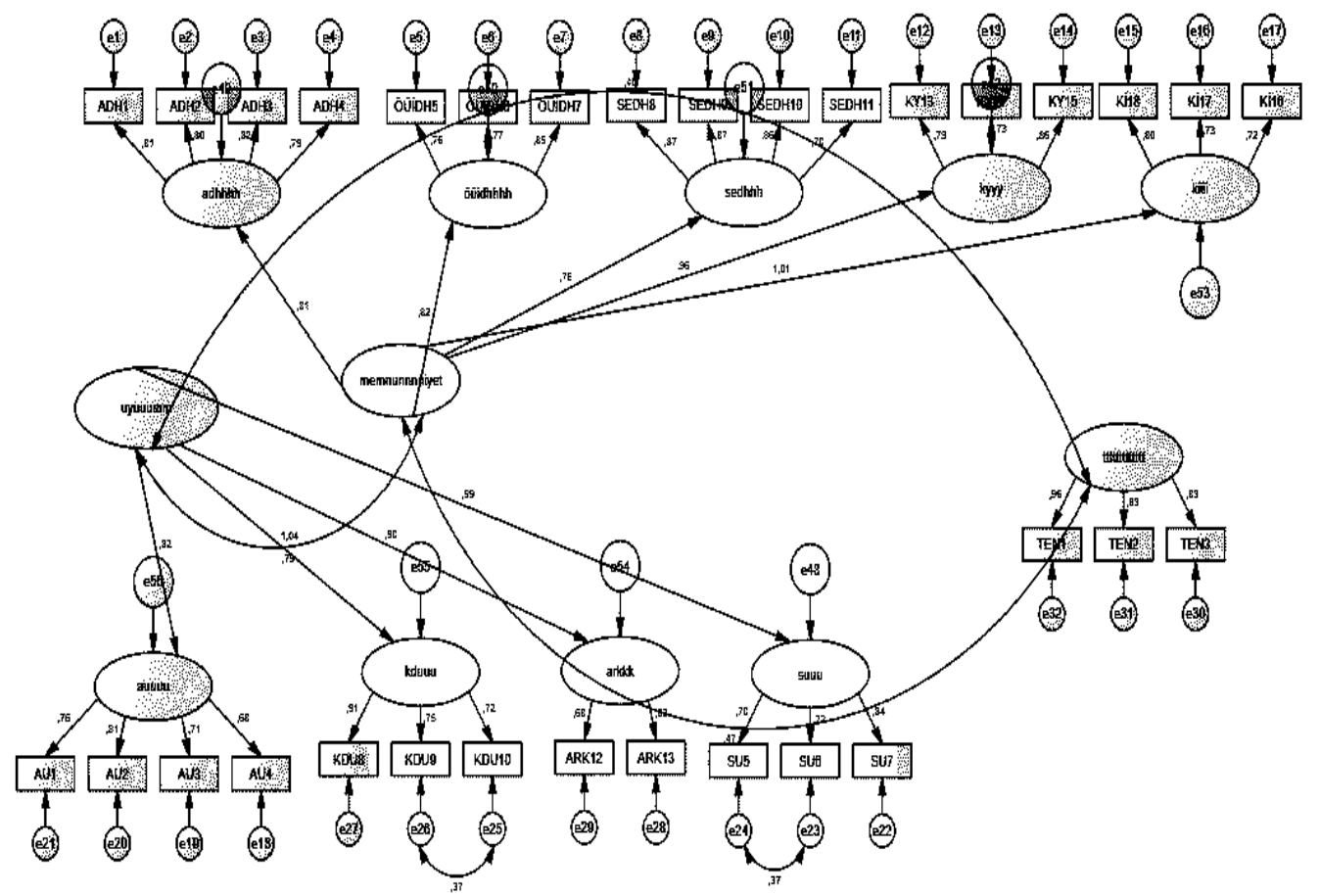


Tablo 4: Uyum Değerleri ve Uyum Aralıkları

\begin{tabular}{l|l|l}
\hline Model Uyum Kriteri & İyi Uyum & Kabul Edilebilir Uyum \\
\hline CMIN/DF & $\chi 2 / \mathrm{df} \leq 3$ & $\chi 2 / \mathrm{df} \leq 5$ \\
RMSEA & RMSEA $\leq 0,05$ & RMSEA $\leq 0,08$ \\
\hline
\end{tabular}

Kaynak: Öztürk ve Faiz (2020)

Tablo 5: Araştırmaya ilişkin Doğrulayıcı Faktör Analizi Sonuçları

\begin{tabular}{l|l|l|l|l}
\hline Model Uyum Kriteri & İyi Uyum & Kabul Edilebilir Uyum & Ölçüm Değeri & Uyum \\
\hline CMIN/DF & $\chi 2 / \mathrm{df} \leq 3$ & $\chi 2 / \mathrm{df} \leq 5$ & 2,150 & İyi Uyum \\
RMSEA & RMSEA $\leq 0,05$ & RMSEA $\leq 0,08$ &, 077 & Kabul Edilebilir \\
\hline
\end{tabular}

Modelde daha iyi bir uyum sağlamak amacıyla Modification Indices menüsünden yüksek oran gösteren hata terimleri arasında kovaryanslar oluşturulmuştur. e9 ve e10 hata terimleri arasında kovaryans etki değeri 31,943, e5 ve e16 hata terimleri arasında kovaryansetki değeri ise 16,767 olduğundan kovaryans oluşturulmuştur. Kovaryans oluşturulduktan sonra model daha anlamlı hale gelmiştir.

Modele ait standardize edilmiş regresyon katsayıları incelendiğinde ise düşük değer gösteren SEDH12 $(, 562)$ ve KDU11 $(, 553)$ maddeleri modelden çıkarılmıştır. Modele ait diğer tüm maddelerin standardize edilmiş regresyon katsayıları Tablo 6’da sunulmuştur.

Tablo 6: Madde Standardize Edilmiş Regresyon Katsayıları

\begin{tabular}{l|l|l|l|l|l}
\hline Madde & Katsayı & Madde & Katsayı & Madde & Katsayı \\
\hline ADH &, $\mathbf{8 0 6}$ & KY & $\mathbf{9 5 9}$ & SU5 &, 701 \\
\hline ADH1 &, 811 & KY13 &, 786 & SU6 &, 724 \\
ADH2 &, 799 & KY14 &, 732 & SU7 &, 843 \\
ADH3 &, 819 & KY15 &, 855 & KDU & $\mathbf{1 , 0 4 2}$ \\
ADH4 &, 791 & Ki & $\mathbf{1 , 0 1 1}$ & KDU8 &, 905 \\
\hline ÖiDH &, 816 & Ki16 &, 719 & KDU9 &, 751 \\
\hline ÖiDH5 &, 757 & Ki17 &, 726 & KDU10 &, 717 \\
ÖiDH6 &, 766 & Ki18 &, 815 & ARK &, 898 \\
ÖiDH7 &, 846 & AU &, $\mathbf{8 1 9}$ & ARK12 &, 676 \\
\hline SDH &, 760 & AU1 &, 764 & ARK13 &, 818 \\
\hline SDH8 & AU2 &, 814 & TEN1 &, 958 \\
SDH9 & A70 &, 705 & TEN2 &, 854 \\
SDH10 &, 870 & AU3 &, 679 & TEN3 &, 834 \\
SDH11 &, 763 & SU &, $\mathbf{9 8 9}$ & & \\
\hline
\end{tabular}

Tablo 6 'da görüldüğü üzere tabloda verilen maddelerin standardize edilmiş regresyon katsayıları 0,7'ye yakın ya da 0,7'den büyüktür. Maddelerde yer alan katsayılar ilgili maddenin bulunduğu boyutta 1 değerinde standart sapma artında katsayı değeri kadar standart sapma yaşanacağı anlamına gelmektedir.

AMOS üzerinde hipotez testleri için analiz yapıldığında ise $H_{1}, H_{2}$ ve $H_{3}$ hipotezleri alt hipotezleri ile beraber kabul edilmiştir. Hipotez testlerine ait $\mathrm{P}$ değerleri Tablo $7^{\prime}$ de sunulmuştur. 
Tablo 7: Hipotez Testi Sonuçları

\begin{tabular}{|c|c|c|c|}
\hline Hipotez & Öncül & $\mathbf{P}$ & Kabul/Ret \\
\hline $\mathrm{H}_{1}$ & Uyum ve öğrenci memnuniyeti arasında pozitif yönde bir ilişki bulunmaktadır. & $* * *$ & Kabul \\
\hline $\mathrm{H}_{2}$ & $\begin{array}{l}\text { Öğrenci memnuniyeti ve tavsiye etme niyeti arasında pozitif yönde bir ilişki } \\
\text { bulunmaktadır. }\end{array}$ & $* * *$ & Kabul \\
\hline $\mathrm{H}_{3}$ & Uyum ve tavsiye etme niyeti arasında pozitif yönde bir ilişki bulunmaktadır. & $* * *$ & Kabul \\
\hline $\mathrm{H}_{4}$ & $\begin{array}{l}\text { Öğrenci memnuniyetinin uyum ve tavsiye etme niyeti arasında aracılık rolü } \\
\text { bulunmaktadır. }\end{array}$ & $* * *$ & Kabul \\
\hline
\end{tabular}

Tablo 7'ye göre uyumun memnuniyet ve tavsiye etme, memnuniyetin de tavsiye etme ile istatistiki olarak anlamlı bir pozitif yönlü ilişkisi vardır. Daha fazla uyum gösteren öğrencilerin memnuniyetlerinin daha fazla olduğu ve memnun kalmış öğrencilerin de daha fazla tavsiye etme davranışı gösterdiği söylenebilir.

\section{Aracilık Analizi}

Aracılık analizinin temel amacı, bağımsız değişken X'in bağımlı değişken $Y$ üzerindeki nedensel etkisinin aracıdan kaynaklanıp kaynaklanmadığını kontrol etmektir. Dolayısıyla aracı eklendikten sonra bağımsız değişken ile bağımlı değişken arasındaki ilişkinin bir kısmı veya tamamı açıklanmalıdır. Dolaylı etkinin toplam etkiye oranı daha büyükse, daha yüksek bir aracılık etkisine işaret eder. Baron ve Kenny (1986) tarafından önerilen aracılık modelinin üç regresyon denklemi aşağıdaki gibidir:

1. Bağımsız değişkenin aracı değişken üzerinde etkisi olmalı,

2. Bağımsız değişkenin bağımlı değişken üzerinde etkisi olmalı,

3. Son olarak, aracı değişkenin bağımlı değişken üzerinde bir etkisinin olması gerekmektedir.

Eğer verilen üç şart uyum sağlıyorsa ikinci adımda verilen analize aracı değişken de eklenir ve bağımlı değişken üzerinde bağımız değişkenle aracı değişkenin birlikte yaptığı etkiye bakılmaktadır. Analiz sonucunda bağımsız değişkenle bağımlı değişken arasında anlamsızlık çıkıyorsa tam aracılık etkisinden, bağımsız değişkenle bağımlı değişken arasındaki anlamlııkta bir azalma meydana geliyorsa kısmi aracılık etkisinden bahsedilmektedir (Baron ve Kenny, 1986; Öztürk ve Faiz, 2020). Bu bilgiler doğrultusunda modele ait aracı değişken analizi Tablo 8 'de sunulmaktadır.

Tablo 8: Aracı Değişken Analizi

\begin{tabular}{l|l|l}
\hline Adım 1 & $\mathrm{P}^{* * *}$ & Estimate: , 358 \\
\hline Uyum - Tavsiye Etme Niyeti & $\mathrm{P}^{* * *}$ & \\
Uyum - Memnuniyet & $\mathrm{P}^{* * *}$ & \\
Memnuniyet - Tavsiye Etme Niyeti & $\mathrm{P}:, 360$ & Estimate: 0,92 \\
\hline Adım 2 & Standardized Indirect Effect (Two Tailed Significant): $0,008<0,05$ \\
\hline
\end{tabular}

Tablo 8'de verilen değerler incelendiğinde ilk olarak uyumun tavsiye etme niyeti üzerindeki etkisinin anlamlı olup olmadığı incelenmiştir. Bu doğrultuda oluşturulan model test edildiğinde $p$ değerinin anlamlı ve katsayısının da ,358 olduğu görülmektedir. Araştırmada yer alan tüm değişkenler birlikte test edildiğinde ikinci adımda uyum ve tavsiye etme niyeti 
arasında hem $\mathrm{p}$ değerinin hem de katsayının bozulduğu görülmektedir. Standardize edilmiş dolaylı etkiye bakıldığında ise significant değerinin 0,05 ten küçük olduğunu ve dolayısıyla memnuniyetin uyum ve tavsiye etme niyeti arasında tam bir aracı değişken rolü oynadığını söyleyebiliriz. Bu durumda $\mathrm{H}_{4}$ hipotezi de kabul edilmiştir.

\section{Tartışma ve Sonuç}

Gelişmiş ülkelerin öncülüğünde ortaya çıkan "yeni yükseköğretim" kavramının getirdiği yenilikler yükseköğretim kurumunun bilgi çağına uyum sağlayabilen, yaratıcı, verimli, rekabetçi gibi özellikler taşımasıdır. Bundan ötürü yükseköğretim pazarı tüm dünyada ciddi bir rekabetin olduğu ve önemli aktörlerin bulunduğu bir pazara dönüşmektedir. Bu pazarda çoğu üniversite bünyesine nitelikli öğrencileri çekmek amacıyla bir rekabete girişmiştir. Bu durum yükseköğretim kurumlarının hâlihazırda yer alan eğitim hizmetlerini pazara sunulan bir değer önerisine dönüştürecek uygun pazarlama anlayışına olan gerekliliğini vurgulamaktadır. Bunun sebebi ise neredeyse dünyada yer alan tüm üniversitelerin pazarlama anlayışına dayalı bir yapılanma ile kendini inşa etmesidir (Akkutay, 2017: 3). Bu duruma bağlı olarak yükseköğretim kurumları hem öğretim faaliyetleri hem de kampüs içi diğer olanakları ile öğrencileri, paydaşları ve çevresi için değer yaratan kurumlar olmak durumundadır. Aksi takdirde tercih edilen bir kurum olmaktan uzaklaşacaklardır. Üniversiteler özelinde, verilen hizmetin karmaşık doğası değer yaratma süreçlerini zorlaştırmaktadır. Üniversitedeki öğretim üyeleri, yönetim kurulları, idari personel, yerel veya ulusal otoriteler gibi çeşitli aktörler ile kültür, ekonomik kaynak, hukuki sınırlılıklar ve üniversitenin itibarı gibi çeşitli faktörler bu karmaşık ve zor doğanın ortaya çıkmasını sağlamaktadır (Díaz-Méndez ve Gummesson, 2012).

Bu çalışmanın amacı daha önce de belirtildiği üzere uluslararası öğrencilerin memnuniyet ve uyumunun tavsiye etme niyeti üzerindeki etkisini tespit etmektir. Bunu da bir uluslararası değişim programı olan Erasmus+ Programına katılmış olan öğrencilerin deneyimleri üzerine bir araştırma yaparak yerine getirmektedir. Bu bağlamda bu çalışmada memnuniyet; akademik destek hizmetleri, fakülte ilişkileri ve destek hizmetleri, sosyal etkileşim ve destek hizmetleri, kampüste yaşam ve kampüs iklimi boyutlarıyla, uyum ise akademik uyum, sosyal uyum, kişisel duygusal uyum ve arkadaşlık boyutlarıyla incelenmiştir.

Araştırma sonuçlarına göre, uyum öğrenci memnuniyeti ve de tavsiye etme niyeti üzerinde istatistikî olarak anlamlı bir etkiye sahiptir. Aynı şekilde öğrenci memnuniyeti de tavsiye etme niyeti üzerinde istatistikî olarak anlamlı bir etkiye sahiptir. Ayrıca memnuniyet; uyum ve tavsiye etme niyeti arasında tam aracı rol oynamaktadır. Sonuçlar literatürle karşılaştırıldığında Abe ve arkadaşları (1998), uluslararası öğrencilerin sosyal uyumu konusunda, arkadaşlığın önemli olduğunu tespit etmiştirler. Brayla (2015)'ın yaptığı çalışmaya göre uluslararası öğrencilerin tatmininde en geniş etkilerden birisi arkadaşlıktır. Bu bulgu $\mathrm{H}_{1 d}$ hipotezini destekler niteliktedir. Rajapaksa ve Dundes (2002), uyum konusunda sosyal ağın önemli olduğunu tespit etmekle beraber sosyal ağdan tatminin uyum ile yakın bir ilişkide olduğunu da bulmuşlardır. Bu araştırmayla ortaya konulan benzer bulgu söz konusu araştırma bulgularını pekiştirmektedir. Benzer şekilde Brein ve David (1971), Bastien ve arkadaşlarına (2018) göre, uluslararası öğrencilerin yükseköğretim kurumuna uyumu konusunda kişisel duygusal uyum ve akademik uyum önem taşımaktadır. Sosyal etkileşimin uluslararası öğrencilerin gösterdiği uyumda etkili olması farklı çalışmalarda (Bui vd., 2020; Gomes vd., 2014) desteklendiği gibi bu çalışmada da ortaya konulmaktadır. Ek olarak Zhai (2002)'nin Birleşik Krallık'ta yaptığı bir araştırmaya göre uluslararası öğrenciler için en önemli meselelerden biri eğitim sistemi, kültürel farklılık ve dil konusudur. Arambewela ve Hall 
(2009), uluslararası öğrencilerin hem eğitimsel hem de eğitimsel olmayan konularda hizmet kalitesine önem verdiğinden bahsetmiştir.

Yükseköğretimde işletme bakış açısının artan etkisi ile birçok eğitim-öğretim faaliyeti pazarın işleyiş biçimlerine yakın bir şekilde yapılmaya başlamıştır. Entelektüel kaynaklar için rekabet etmelerinden ötürü birçok üniversite pazara sundukları ürün ve hizmetlerini çeşitlendirmek ve yeni pazarlara giriş fırsatları geliştirmek gibi rekabet stratejilerini kullanmaya başlamışlardır (Oleksiyenko vd., 2013). Bu noktada paydaşların tavsiye etme davranışlarının önemi ortaya çıkmaktadır. Özellikle akranların birbirlerine ticari veya kurumsal olmayan iletişimler ile bu mesajları aktarması değerli olmaktadır. Bu bağlamda yükseköğretim kurumları özellikle rekabet etme konusunda ağızdan ağıza pazarlama yöntemini kullanarak tavsiye edilebilirliklerini yükseltebilirler. Chen (2008: 28), aynı zamanda çoğu uluslararası öğrencinin gelecekte uluslararası bir ortamda çalışmak istediklerini belirtmektedir. Bu durum, üniversite ne kadar çok uluslararası faaliyette bulunursa profilinin o kadar yüksek olacağı ve uluslararası işverenlerin bu üniversitelerden ve bu programlardan mezun olanlara o kadar aşina olacağı anlamına gelmektedir. Esasen, bu etkinlikler yoluyla yükseköğretimi uluslararasılaştırmak yumuşak veya örtük bir yoldur ve belki de yükseköğretimi uluslararası öğrencilere, özellikle de lisansüstü düzeyde pazarlamanın en iyi yoludur. Ayrıca Ammigan'ın (2019) yaptığı bir çalışmaya göre öğrencilerin tavsiye etme niyetinde uluslararası öğrencilerin varış, öğrenme, yaşama ve destek hizmetlerinden tatmin önem taşımaktadır. Ayrıca arkadaş edinme, uluslararası öğrencilerin tavsiye etme niyetinde en etkili faktör olarak tespit edilmiştir. $\mathrm{Bu}$ da $\mathrm{H}_{3 \mathrm{~d}}$ hipotezini desteklemektedir.

Bu bulgulardan yola çıkarak yükseköğretim kurumlarının uluslararasılaşması yolunda tavsiye etme niyetinin önemli bir niteliğe sahip olduğunu belirtmek yerinde olacaktır. Giderek küreselleşen tüm sektörlerle birlikte yükseköğretim kurumlarının da uluslararasılaşması kaçınılmaz bir gerçektir. Bu değişime ayak uydurmak isteyen yükseköğretim kurumlarının uluslararası öğrencilerin ne istediğine önem vermeleri gerekmektedir. 


\section{Kaynakça}

Abdullah, F. (2006), "Measuring service quality in higher education: HEdPERF versus SERVPERF", Marketing Intelligence \& Planning, Vol. 24, No. 1: 31-47.

Abe, J.; Talbot, D. M.; Gellhoed, R.; Geelhoed, R. J. (1998), "Effects of a peer program on international student adjustment", Journal of College Student Development, Vol. 39, No. 6: 539-547.

Akkutay, E. A. (2017), "Yükseköğretimde Küreselleşme ve Yansımaları", Eğitim ve Toplum Araştırmaları Dergisi, C. 4, S. 1: 1-16.

Amaro, S.; Barroco, C.; Martins, C.; Antunes, J. (2019), “Erasmus students in Portugal: from students to tourists and advocates", European Journal of Tourism Research, Vol. 22: 94-106.

Ammigan, R. (2019), "Institutional satisfaction and recommendation: What really matters to international students", Journal of International Students, Vol. 9, No. 1: 262-281.

Anderson, L. E. (1994), "A new look at an old construct: Cross-cultural adaptation", International journal of intercultural relations, Vol. 18, No. 3: 293-328.

Antwi, R.; Ziyati, A. (1993), "Life Experience of African Graduate Students in a Multi-Cultural Setting: A Case Study, New York: American Educational Research Association. (ERIC), 1-23.

Arambewela, R.; Hall, J. (2009), "An empirical model of international student satisfaction", Asia Pacific Journal of Marketing and Logistics, Vol. 21 No. 4: 555-569.

Athiyaman, A. (1997), "Linking student satisfaction and service quality perceptions: the case of university education", European journal of marketing. Vol. 31, No. 7: 528-540.

Aydın, S.; Tavukçu, A. (2019), “ilişkisel pazarlama uygulamalarının müşteri sadakati, müşteri memnuniyeti ve müşterilerin tavsiye etme eğilimi üzerine etkisi: Türk katılım bankacılı̆̆ı sektöründe bir araştırma”, International Congress on Business and Marketing, 156-172.

Baker, R. W.; Siryk, B. (1999), "SACQ: Student adaptation to college questionnaire: Manual", Los Angeles: Western Psychological Services.

Baron, R. M.; Kenny, D. A. (1986), "The moderator-mediator variable distinction in social psychological research: Conceptual, strategic, and statistical considerations", Journal of personality and social psychology, Vol. 51, No. 6: 1173-1182.

Bastien, G., Seifen-Adkins, T. ve Johnson, L. R. (2018), "Striving for success: Academic adjustment of international students in the US", Journal of International Students, Vol. 8, No. 2: 1198-1219.

Beine, M.; Noel, R.; Ragot, Lionel (2014), "Determinants of the international mobility of students", Economics of Education Review, S. 41: 40-54.

Brein, M.; David, K. H. (1971), "Intercultural communication and the adjustment of the Sojourner", Psychological Bulletin, Vol. 76, No. 3: 215.

Browne, B. A; Kaldenberg, D. O.; Browne, W. G.; Brown, D. J. (1998), "Student as customer: Factors affecting satisfaction and assessments of institutional quality", Journal of Marketing for Higher Education, Vol. 8, No. 3: 1-14.

Bryła, P. (2015), "Self-reported Effects of and satisfaction with international student mobility: A large-scale survey among Polish former Erasmus students", Procedia-Social and Behavioral Sciences, Vol. 191: 2074-2082.

Bui, H. T. N.; Selvarajah, C.; Vinen, D. G; Meyer, D. (2020), “Acculturation: Role of Student-University Alignment for International Student Psychological Adjustment", Journal of Studies in International Education, 1-20.

Chang, D. F. (2012), "College students' perceptions of studying abroad and their readiness". Asia Pacific Education Review, Vol. 13, No. 4: 583-591.

Chen, S. F. (1996), "Learning Multiculturalism from the Experience of International Students: The Experience of International Students in a Teacher Training Program", New York: American Educational Research Association.(ERIC).

Cong, C. (2017), "International students' satisfaction with educational service augmenters and their adjustment to the US higher education institutions", Doctor of Philosophy (PhD), dissertation, Educ Foundations \& Leadership, Old Dominion Universit.

Çetinsaya, G. (2014), “Büyüme, kalite, uluslararasılaşma: Türkiye yükseköğretimi için bir yol haritasi",Yükseköğretim Kurulu Yayın No: 2.

Díaz-Méndez, M.; Gummesson, E. (2012), "Value co-creation and university teaching quality", Journal of Service Management, Vol. 23, No. 4: 571-592.

Dollinger, M.; Lodge, J.; Coates, H. (2018), "Co-creation in higher education: towards a conceptual model", Journal of Marketing for Higher Education, Vol. 28, No. 2: 210-231.

Elliot, K. M.; Shin, D. (2002), "Student Satisfaction: An Alternative Approach to Assessing This Important Concept", Journal of Higher Education Policy and Management, Vol. 24, No. 2: 197-209. 


\section{Eskişehir Osmangazi Üniversitesi İktisadi ve İdari Bilimler Fakültesi Dergisi}

Elliott, K. M; Healy, M. A. (2001), "Key factors influencing student satisfaction related to recruitment and retention", Journal of marketing for higher education, Vol. 10, No. 4: 1-11.

Endo, J. J.; Harpel, R. L. (1982), "The effect of student-faculty interaction on students' educational outcomes", Research in Higher Education, Vol. 16, No. 2: 115-138.

Engel, C. (2010), "The impact of Erasmus mobility on the professional career: Empirical results of international studies on temporary student and teaching staff mobility", Belgeo, Vol. 4: 351-363.

Erişti, B.; Polat, M.; Erdem, C. (2018), "Yükseköğretimde Uluslararasılaşma: Uluslararası Öğrencilerin Bulunduğu Sınıflarda Ders Veren Öğretim Elemanlarının Öğretim Sürecinde Yaşadıkları Sorunlar ve Çözüm Önerileri”, Journal of History Culture and Art Research, C. 7, S. 2: 352-375.

European C. (2014). Effects of mobility on the skills and employability of students and the internationalisation of higher education institutions. Luxembourg: Publications Office Of The European Union.

Gomes, C.; Berry, M.; Alzougool, B.; Chang, S. (2014), "Home away from home: International students and their identity-based social networks in Australia", Journal of International Students, Vol. 4, No. 1: 2-15.

Güriş, S. Ve Astar, M. (2019), "Hipotez Testleri”, Bilimsel Araştırmalarda SSPSS İstatistik, İstanbul: Der Yayınları: 179-308.

Hartman, D. E.; Schmidt, S. L. (1995), “Understanding student/alumni satisfaction from a consumer's perspective: The effects of institutional performance and program outcomes", Research in Higher Education, Vol. 36, No.2: 197217.

Hechanova-Alampay, R.; Beehr, T. A; Christiansen, N. D.; Van Horn, R. K. (2002), "Adjustment and strain among domestic and international student sojourners: A longitudinal study", School Psychology International, Vol. 23, No. 4: 458-474.

Hendrickson, B.; Rosen, D.; Aune, R. K. (2011), "An analysis of friendship networks, social connectedness, homesickness, and satisfaction levels of international students", International journal of intercultural relations, Vol. 35, No. 3: 281-295.

Hunt, H. K. (1977), "Overview and future directions", Conceptualization and measurement of customer satisfaction and dissatisfaction, Marketing Science Institute, 7-23.

Iriondo, I. (2019), "Evaluation of the impact of Erasmus study mobility on salaries and employment of recent graduates in Spain", Studies in Higher Education, Vol. 45, No. 4: 925-943.

Janca, A.; Helzer, J. E. (1992), "Psychiatric morbidity of foreign students in Yugoslavia: a 25 year retrospective analysis", International Journal of Social Psychiatry, Vol. 38, No. 4: 287-292.

Jibeen, T.; Khan, M. A. (2015), "Internationalization of higher education: Potential benefits and costs", International Journal of Evaluation and Research in Education, Vol. 4, No. 4: 196-199.

Khan, M. A.; Omrane, A.; Bank, D. (2016). The role of internationalization in the higher education industry: an exploratory study. International Journal of Economics \& Strategic Management of Business Process, Vol. 7, No. 2: 8699.

Khawaja, N. G; Dempsey, J. (2008), "A comparison of international and domestic tertiary students in Australia", Australian Journal of Guidance and Counselling, Vol. 18, No, 1: 30-46.

Langthaler, M. (2009), "Does globalised education benefit development? Introductory considerations on development and power in the context of internationalisation in tertiary education", Internationalisation of Higher Education and Development. ÖFSE-Edition, Vol.15: 19-31.

Maringe, F.; Foskett, N. (Eds.). (2012). Globalization and internationalization in higher education: Theoretical, strategic and management perspectives. A\&C Black.

Mellors-Bourne, R.; Humphrey, C.; Kemp, N.; Woodfield, S. (2013), "The Wider Benefits of International Higher Education in the UK". Research Paper 128. London: Department for Business. Innovation and Skills, 1-128.

Moreira, L.; Gomes, R. M. (2019), "Study abroad: the influence of city and university attractiveness factors", European Journal of Tourism Research Vol. 22: 79-93.

Oleksiyenko, A., Cheng, K.-M., ve Yip, H.-K. (2013), "International student mobility in Hong Kong: private good, public good, or trade in services?", Studies in Higher Education, Vol. 38, No. 7: 1079-1101.

Oliver, R. L. (1981), "Measurement and evaluation of satisfaction processes in retail settings", Journal of Retailing, Vol. 57, No. 3: 25-48.

Owlia, M. S; Aspinwall, E. M. (1997), "TQM in higher education-a review", International Journal of Quality \& Reliability Management, Vol. 14, No. 5: 527-543.

Öztürk, E.; Faiz, E. (2020), “Algılanan Öğretim Kalitesi ve Öğrenci Tatmininin Öğrenci Sadakati Üzerindeki Etkisi: Düzce Üniversitesi Örneği”, Uluslararası Turizm, Ekonomi ve Iş̧letme Bilimleri Dergisi (IJTEBS) E-ISSN: 2602-4411, C. 4, S. 1: 01-15. 
Parr, G.; Bradley, L.; Bingi, R. (1992), “Concerns and feelings of international students”, Journal of College Student Development, Vol. 33, No. 1: 20-25.

Paswan, A. K; Ganesh, G. (2009), "Higher education institutions: Satisfaction and loyalty among international students", Journal of Marketing for Higher Education, Vol. 19, No. 1: 65-84.

Perez-Encinas, A.; Rodriguez-Pomeda, J. (2017), “International Students' Perceptions of Their Needs When Going Abroad: Services on Demand", Journal of Studies in International Education, Vol. 22, No. 1: 20-36.

Rajapaksa, S.; Dundes, L. (2002), "It's a long way home: International student adjustment to living in the United States", Journal of College Student Retention: Research, Theory \& Practice, Vol. 4, No. 1: 15-28.

Ramsay, S.; Barker, M.; Jones, E. (1999), "Academic Adjustment and Learning Processes: a comparison of international and local students in first-year university", Higher Education Research \& Development, Vol. 18, No. 1: 129-144.

Rienties, B.; Beausaert, S.; Grohnert, T.; Niemantsverdriet, S.; Kommers, P. (2012), "Understanding academic performance of international students: The role of ethnicity, academic and social integration", Higher education, Vol. 63, No. 6: 685-700.

Roy, A.; Newman, A.; Ellenberger, T.; Pyman, A. (2018), “Outcomes of international student mobility programs: a systematic review and agenda for future research", Studies in Higher Education, Vol. 44, No. 9: 1-15.

Russell, J.; Rosenthal, D.; Thomson, G. (2010), "The international student experience: Three styles of adaptation", Higher education, Vol. 60, No.2: 235-249.

Sevier, R. A. (1996), "Those Important Things: What Every College President Needs to Know About Marketing and Student Recruitment", College and University, Vol. 71, No. 4: 9-16.

Suanet, I.; Van de Vijver, F. Jr. (2009), "Perceived cultural distance and acculturation among exchange students in Russia", Journal of Community \& Applied Social Psychology, Vol. 19, No. 3: 182-197.

Thomson, C. P.; English, J. T. (1964), "Premature return of Peace Corps volunteers", Public Health Reports, Vol. 79, No. 12: 1065.

Tinto, V. (1975), "Dropout from higher education: A theoretical synthesis of recent research", Review of educational research, Vol. 45, No. 1: 89-125.

Tinto, V. (1998), "Colleges as communities: Taking research on student persistence seriously", The review of higher education, Vol. 21, No. 2: 167-177.

Trice, A. G.; Yoo, J. E. (2007), “International graduate students' perceptions of their academic experience", Journal of Research in International Education, Vol. 6, No. 1: 41-66.

Wang, R.; Tseng, M. L. (2011), "Evaluation of International Student Satisfaction using Fuzzy ImportancePerformance Analysis", Procedia - Social and Behavioral Sciences, Vol. 25: 438-446.

Westbrook, R. A. (1980), "Intrapersonal affective influences on consumer satisfaction with products", Journal of consumer research, Vol. 7, No. 1: 49-54.

Yemini, M.; Holzmann, V.; Fadilla, D.; Natur, N.; Stavans, A. (2014), “Israeli college students' perceptions of internationalisation", International Studies in Sociology of Education, Vol. 24, No. 3: 304-323.

Zhai, L. (2002). "Studying International Students: Adjustment Issues and Social Support", the educatıonal resources informatıon center, New York: American Educational Research Association. (ERIC), 1-20. 


\section{Extended Summary}

\section{The Effect of International Exchange Students' Satisfaction and Adaptation on the Intention to Recommend: Example of Eskişehir Osmangazi University}

Starting from the Industrial Age until the 21st century, knowledge has continuously developed and emerged in different ways and it ultimately has transformed into a new form of capital in the 21st century. In addition to the physical ones, intellectual assets have gained importance for institutions. When developing countries are especially taken into consideration, knowledge bears much more significance for the development and improvement of these countries. Educational institutions also play a crucial role in keeping up with the information age and in parallel with this key role, a novel concept called "new higher education" has emerged under the leadership of developed countries. This concept expresses that the higher education institution has such characteristics as being able to adapt to the information age, being creative, efficient, and competitive. For this reason, outstanding actors from all over the world have started to show themselves up in the higher education market. Most higher education institutions have engaged in a competition to attract qualified foreign students within this market. This situation reveals the importance of marketing strategies for higher education institutions to transform their current education services into a value item to be marketed. The intention to recommend, which allows an action performed by one person to be carried out by other people, is one of the tools that can be used in higher education marketing.

The internationalization of higher education institutions plays a key role in keeping up with the information age and international students play a direct role in the internationalization of higher education institutions. International students not only economically and culturally contribute to the host country, but they also transform the education and training services and the system itself established within the institution. Outgoing students also get to know the education system in the host country and acquire different skills. In this case, they add an added value to the country of origin. In order these cases to be realised, students are expected to be satisfied with the learning experience. It is also important that the student adapts to the relevant higher education system and institution in terms of satisfaction. There are many studies that examine the factors that push and pull international students. When the relevant studies in the literature are examined, the antecedents of students' satisfaction are observed as language skills, social circle, educational environment, lectures, academic staff, the image of the university, accommodation and economic situation. When the adaptation factors are examined, although the emphasis is mostly on social adaptation, such factors as adaptation to academic courses, adaptation to campus environment, harmony with circle of friends, and personal emotional adaptation come to the fore.

Higher education institutions carry out various programs to attract international students. International students can be both full-time students starting from the first year of the educational level until the graduation, and an exchange student attending only a certain period of the education program. Another program that provides exchange mobility for students is the Erasmus+ Exchange Program by which students can carry out short-term study and/or internship mobility in a different higher education institution abroad, which has a bilateral agreement with the higher education institutions they are enrolled in.

In this study, the relationship between the satisfaction and adaptation level of international students carrying out mobility through Erasmus+ Exchange Program and their intention to recommend has been examined. The student satisfaction has been analysed in terms of academic support services, relationship with faculty members, support services, social interaction, campus life and campus climate. Adaptation, on the other hand, has been examined in terms of academic adaptation, social adaptation, personal-emotional adjustment and friendship. The population of the research consists of Eskişehir Osmangazi University students who went abroad through Erasmus+ Learning Mobility Programme in academic years of 2013-2014, 2014-2015, 2015-2016, 2016-2017, 2017-2018, 20182019, and 2019-2020. Accordingly, an online questionnaire composed of 47 questions, 37 statements in 5 Point-Likert Type and 10 questions examining demographic variables, was sent to the students via e-mail. Data collection process lasted 4 weeks. At the end of the process, a total of 197 valid responses were obtained. The validity and reliability coefficients of the scales used in the study have been found as quite high. Linear relationships between dimensions in the study were analysed using structural equation modelling through the AMOS Program.

It has been found according to the research findings that the adaptation factor has a statistically significant effect on student satisfaction and the intention to recommend. Likewise, student satisfaction has a statistically significant effect on the intention to recommend. Besides, satisfaction plays a full mediating role between adaptation and the intention to recommend. Similarly, the sub-dimensions of the constructs in the research have a statistically significant effect on each other as stated in the research model

The concept of "new higher education", which emerged under the leadership of developed countries, has brought about such novelties for higher education institutions as being able to adapt to the new knowledge era, 
being creative, efficient, and competitive. Therefore, the higher education market is turning into a market where serious competition is experienced and significant actors from all over the world have started to play a key role. Based on this, satisfaction and adaptation factors are important for international students in terms of the intention to recommend, which contributes to the dissemination of internationalization activities in higher education institutions and has a significant place in the marketing literature. Higher education institutions keen on improving their internationalization activities should pay attention to these factors. At this point, the importance of the recommendation behavior of the partners emerges. It is especially of significant value for peers to transfer these messages to each other through commercial or non-institutional ways of communication. In this context, higher education institutions can increase their level of recommendation by using word of mouth marketing method particularly to increase their competitiveness. 